\title{
Pengaruh Net Profit Margin (NPM) Terhadap Return Saham Pada Sektor Otomotif Dan Komponen Yang Terdaftar Di Bursa Efek Indonesia (BEI) Tahun 2015-2018
}

\author{
Mursalin \\ Akuntansi, FE Universitas PGRI Palembang, mursalin@univpgri-palembang.ac.id
}

\begin{abstract}
The purpose of this study was to examine the effect of the Net Profit Margin variable on Stock Return. The subject of this study was the Automotive Sector and Component companies listed on the Indonesia Stock Exchange (IDX) in the 2015-2018 period. The data used in this study are secondary data, namely financial statement data and social responsibility reports contained in the annual report (annual report) on the automotive sector companies and Components listed on the Indonesia Stock Exchange in 2015-2018. Data analysis and discussion are carried out using descriptive statistical methods, namely statistics used to analyze data by describing or describing data that has been collected as it is without intending to make conclusions that apply to the public or generalizations. The results of this study partially indicate that the simple regression test is 3.388 , meaning that if the independent variable value is 0 , then the Stock Return will remain at 3.388. While Net Profit Margin has a regression coefficient has a negative direction that is -0.377 , meaning that every change in the variable NPM $(X)$ by $1 \%$, it will result in changes in Stock Return of -0.377 . While the t test of Net Profit Margin (NPM) has significant and significant effect on Stock Returns.
\end{abstract}

Keywords: Net Profit Margin and Stock Return.

\begin{abstract}
ABSTRAK
Tujuan penelitian ini untuk menguji pengaruh variabel Net Profit Margin terhadap Return Saham subjek penelitian ini adalah perusahaan Sektor Otomotif dan Komponen yang terdaftar di Bursa Efek Indonesia (BEI) pada periode 2015-2018. Data yang digunakan dalam penelitian ini adalah data sekunder, yaitu data laporan keuangan dan laporan tanggung jawab sosial yang terdapat dalam laporan tahunan (annual report) pada perusahaan sektor otomotif dan Komponen yang terdaftar di Bursa Efek Indonesia tahun 2015-2018. Analisis data dan pembahasan dilakukan dengan menggunakan metode statistik deskriptif yaitu statistik yang digunakan untuk menganalisis data dengan cara mendeskripsikan atau menggambarkan data yang telah terkumpulkan sebagaimana adanya tanpa bermaksud membuat kesimpulan yang berlaku untuk umum atau generalisasi. Hasil penelitian ini secara parsial menunjukkan bahwa uji regresi sederhana konstanta yaitu 3,388, artinya jika variabel independen nilainya adalah 0, maka Return Saham akan tetap sebesar 3,388. Sedangkan Net Profit Margin memiliki koefisien regresi mempunyai arah negatif yaitu $-0,377$, artinya setiap perubahan variabel NPM (X) sebesar 1\%, maka akan mengakibatkan perubahan Return Saham sebesar $-0,377$. Sedangkan uji t Net Prrofit Margin (NPM) berpengaruh dan signifikan terhadap Return Saham.
\end{abstract}

Kata Kunci: Net Profit Margin dan Return Saham.

\section{A. Pendahuluan}

Motivasi atau tujuan para investor untuk melakukan investasi dipasar modal tidak selalu sama. Bagi investor yang mempunyai tujuan untuk keuntungan jangka pendek, pada umumnya mereka menginginkan bagian dari keuntungan yang cepat yaitu berupa capital gain dengan cara membeli saham atau sekuritas lain pada saat harganya murah dan menjualkan pada saat harga saham meningkat. Sedangkan bagi investor yang ingin mendapatkan keuntungan jangka panjang berupa keinginan 
untuk memperoleh proporsi kepemilikan diperusahaan, pada umumnya mereka kurang menanggapi terjadinya fluktuasi harga saham.

Faktor-faktor yang mempengaruhi naik turunnya harga saham yaitu faktor mikro perusahaan dan faktor makro ekonomi. Faktor mikro (internal perusahaan) yang mempengaruhi harga saham yaiu tingkat keuntungan yang diperoleh perusahaan, tingkat risiko yang dihadapi dan kinerja perusahaan tersebut. Sedangkan faktor makro (eksternal perusahaan) adalah tingkat inflasi, nilai tukar atau kurs rupiah, keadaan perekonomian dan kondisi sosial politik negara yang bersangkutan.

Seiring dengan semakin pesatnya perdagangan saham dan tingginya tingkat risiko saham, maka kebutuhan akan informasi yang relevan dan memadai bagi investor dalam pengambilan keputusan investasi juga meningkat. Informasiinformasi tersebut diperlukan untuk mengetahui variabel-variabel yang mempengaruh dengan fluktuasi terhadap return saham.

Salah satu informasi-informasi yang tepat dan akurat mengenai kinerja dan kondisi keuangan perusahaan. Agar seorang investor bisa melakukan pengambilan keputusan dalam berinvestasi di pasar modal, maka kinerja dan kondisi keuangan dari perusahaan dapat di percaya. Seorang invesor mempunyai tujuan utama yaitu untuk mendapatkan hasil (return) yang tinggi.

Di tengah sedang tidak stabilnya perekonomian yang salah satunya disebabkan dengan naiknya harga bahan bakar minyak (BBM) di indonesia, perusahaan di sektor industri otomotif dan komponen diprediksi akan menunjukan pertumbuhan yng positif seiring dengan disetujuinya program mobil murah dan rendah emisi oleh produser mobil kepada pemerintah.sehingga diharapkan kebutuhan dan komponen atau sparepart otomotif juga mengalami pertumbuhan yang positif.

Dengan peningkatan pertumbuhan industri sektor otomotif dan komponen ini, maka akan menarik minat para investor untuk menanamkan modalnya pada industri ini. Masih menjadi suatu pengambilan saham yang di dapat juga akan meningkat, karena penanaman modal yang pesat akan berdampak pada kegiatan operasional perusahaan untuk memproduksi produk juga akan semakin besar, yang kemudian berdampak pula atas profit yang dihasilkan.

Profit yang tinggi tidak menjamin bahwa harga saham perusahaan juga akan mengalami peningkatan, hal ini dikarenakan untuk perusahaan yang sedang mengalami pertumbuhan pesar cenderung akan melakukan ekspansi atau investasi untuk mengembangkan usaha, sehingga memerlukan dana yang lebih besar dalam liabilitasdari pihak luar, liabilitas yang besar dipandang investor suatu hal yang negatif (risiko tinggi) untuk investasi dan akan mempengaruhi fluktuatifnya harga saham yang membentuk pengambalian saham yang di dapat dari investasi.

\section{B. Kajian Teori}

1) Net Profit Margin (NPM)

Menurut Kasmir (2014:199) Net Profit Margin (NPM) merupakan hubungan antara laba bersih setelah pajak dengan penjualan menunjukkan kemampuan manajemen dalam mengendalikan harga pokok barang dagangan/jasa, beban operasi, penyusutan, bunga pinjaman, dan pajak.

Menurut Diana (2018:62) Net Profit Margin (NPM) adalah untuk mengukur kemampuan perusahaan dalam mendapatkan laba bersih dari penjualan. Rasio ini menunjukan berapa besar persantase pendapatan bersih yang didapatkan perusahaan dari setiap penjualan. Rasio ini mengukur rupiah laba bersih yang 
diperoleh setiap satu rupiah penjualan semakin besar rasionya maka makin baik, artinya posisi pemilik perusahaan dalam mendapatkan laba cukup tinggi pada tingkat penjualan tertentu. Apabila rasionya rendah berarti menunjukkan penjualan yang terlalu rendah untuk tingkat biaya tertentu. Sehingga secara matematis $\mathrm{Net}$ Profit Margin dapat di rumuskan sebagai berikut:

Net Profit Margin=

Laba Bersih Setelah Pajak (EAT) X 100\% Peniualan

\section{2) Return Saham}

Menurut Jogiyanto (2014:235) return saham adalah hasil yang diperoleh dari investasi saham. Return dapat berupa return realisasian yang sudah terjadi atau return ekspektasian yang belum terjadi tetapi yang diharapkan akan terjadi di masa mendatang.

Sedangkan Menurut Fahmi (2015:189) return saham adalah tingkat keuntungan yang dinikmati oleh pemodal atas investasi saham yang dilakukannya. Return merupakan laba investasi, baik melalui bunga ataupun dividen.

Return saham yaitu pendapatan atau keuntungan yang diperoleh dalam bentuk persentase dari modal awal investasi serta mendapat imbalan atas keberanian investor dalam berinvestasi, yaitu bahwa pemodal harus selalu mempertimbangkan ukur ketidakpastian yang merupakan risiko investor.

1. Jenis-jenis Return Saham

Menurut Hartono (2014:263), return saham terdiri dari dua yaitu :

a. Returnrealisasian (realized return)

Merupakan return yang telah terjadi return realisasian dihitung menggunakan data historis, return realisasian penting karena digunakan sebagai salah satu pengukur kinerja dari perusahaan. Return realisasian atau return histori ini juga berguna sebagai dasar penentuan return ekspektasian (expected return) dan risiko di masa datang.

b. Return ekspektasian (expected return)

Merupakan return yang diharapkan akan diperoleh oleh investor di masa mendatang. Berbeda dengan return realisasian yang sifatnya sudah terjadi, return ekspektasian sifatnya belum terjadi.

2. Komponen Return Saham

Menurut Sunariyah $(2011: 48)$ return saham terdiri dari dua komponen, yaitu:

a. Capital gain (loss)

Capital gain (loss) yaitu kenaikan (penurunan) harga suatu saham yang biasa memberikan keuntungan (kerugian) bagi investor.

b. Yield

Yield merupakan komponen return yang mencerminkan aliran kas atau pendapatan yang diperoleh secara periode dari suatu investasi saham.

3. Faktor-faktor yang Mempengaruhi Return Saham

Beberapa faktor yang mempengaruhi return saham dapat dilihat dari kinerja keuangan perusahaan dengan mengenalisis laporan keuangan perusahaan yang bersangkutan. Pemilihan aspek-aspek yang akan dinilai perlu dikaitkan dengan tujuan analisis seorang pemodal atau investor akan lebih berkepentingan dengan kemampuan perusahaan dalam menghasilkan keuntungan. 
Menurut Sunariyah (2011:49) deviden adalah pembagian keuntungan yang diberikan perusahaan penerbit saham atas keuntungan yang dihasilkan perusahaan. Deviden yang dibagikan dapat berupa deviden tunai (cash devidend) dan deviden saam (stock deviden).

Investor yang bentuk menerima deviden adalah investor memegang saham hingga batas waktu yang ditentukan oleh perusahaan pada saat pengumuman deviden. Sedangkan capital gain terbentuk dengan adanya aktivitas perdagangan saham dipasar skunder. Jika harga saham sekarang $\left(p_{t}\right)$ lebih tinggi dari pada periode sebelumnya $\left(\mathrm{P}_{\mathrm{t}-1}\right)$ maka pemegang saham mengalami capital gain. Jika yang terjadi sebaliknya, maka pemegang saham mengalami capital loss.

Besarnya capital gain atau capital loss dapat dihitung dengan menggunakan rumus sebagai berikut:

$$
\begin{aligned}
& \begin{array}{l}
\boldsymbol{R}=\underline{\boldsymbol{P}_{t}}-\left(\boldsymbol{P}_{\mathrm{t}}-1\right) \\
\boldsymbol{P t}^{\mathrm{1}} \mathbf{1}
\end{array} \\
& \text { Keterangan: } \\
& \mathrm{R} \quad=\text { Return saham } \\
& \mathrm{P}_{\mathrm{t}} \quad=\text { Harga saham sekarang } \\
& \mathrm{P}_{\mathrm{t}-1}=\text { Harga saham periode } \\
& \text { sebelumnya }
\end{aligned}
$$

\section{Saham}

Menurut Fahmi (2015:81) saham merupakan salah satu instrumen pasar modal yang paling banyak diminati oleh investor, karena mampu memberikan tingkat pengembalian yang menarik. Saham adalah kertas yang tercantum dengan jelas nilai nominal, nama perusahaan, dan diikuti dengan hak dan kewajiban yang telah dijelaskan kepada setiap pemegangnya.

Menurut Jogiyanto (2014:35) saham (stock) terdapat tiga jenis saham yaitu:

a) Saham biasa adalah saham yang mana jika perushaan hanya mengeluarkan satu kelas saham. Saham biasa sendiri memilik hak untuk pemegangnya di antaranya hak kontrol, hak menerima pembagian keuntungan, dan hak presentasi.

b) Saham preferen merupakan saham yang sifat gabungan antara obligasi dan saham biasa. Pada saham ini sendiri memiliki banyak keistimewaan.

c) Saham Treasuri adalah saham milik perusahaan yang sudah pernah dikeluarkan dan beredar yeng kemudian dibeli kembali oleh perusahaan untuk disimpan sebagai treasuri yang nantinya dapat dijual kembali.

\section{3) Pasar Modal}

Menurut Widoatmodjo (2012:15) pasar modal menurut adalah pasar abstrak, dimana yang diperjualbelikan adalah dana-dana jangka panjang, yaitu dan yang keterikatannya dalam investasi lebih dari satu tahun.

Menurut Fahmi (2015:48) pasar modal adalah tempat dimana berbagai pihak khususnya menjual saham (stock) dan obligasi (bond) dengan tujuan dari hasil penjualan tersebut nantinya akan dipergunakan sebagai tambahan dan atau untuk memperkuat modal perusahaan. 


\section{Metode Penelitian}

Metode penelitian yang digunakan dalam penelitian ini adalah metode penelitian kuantitatif. Metode kuantitatif adalah analisis yang menggunakan rumusrumus statistika yang sesuaikan dengan judul penelitian dan rumusan masalah, untuk memperhitungkan angka-angka dalam rangka menganalisa data yang diperoleh, karena memperhitungkan Net Profit Margin (NPM) terhadap Return saham pada sektor otomotif dan komponen yang terdaftar di Bursa Efek Indonesia.

\section{Populasi dan Sampel}

1. Populasi

Populasi dalam penelitian ini adalah laporan keuangan pada perusahaan sektor otomotif dan komponen yang terdaftar di Bursa Efek Indonesia pada periode 2015, 2016, 2017, dan 2018 yaitu sebanyak 12 perusahaan.

\section{Sampel}

Sampel yang digunakan dalam penelitian ini adalah sampel yang memenuhi kriteria tertentu. Tujuan dari kriteria tersebut adalah untuk menghindari adanya kesalahan spesifikasi yang akhirnya dapat mempengaruhi hasil analisis yang dihasilkan.

Yang menjadi kriteria dalam penelitian ini adalah sebagai berikut:

a. Perusahaan sektor otomotif dan komponen yang terdaftar di BEI dalam periode 2015, 2016, 2017, dan 2018.

b. Perusahaan sektor otomotif dan komponen yang memiliki laba bersih selama periode pengamatan.

c. Perusahaan yang sudah IPO (initial public oddering) dari tahun 2015, 2016, 2017, dan 2018.

d. Perusahaan yang diteliti memiliki data keuangan yang lengkap dan memberikan laporan keuangan selama periode pengamatan.

e. Perusahaan yang diteliti memperoleh laba selama periode pengamatan.

Sampel dalam penelitian ini adalah sebanyak 8 perusahaan, yaitu:

Tabel 1

Daftar Sampel

\begin{tabular}{|c|c|c|}
\hline No & Kode Saham & Nama Emiten \\
\hline 1 & ASII & Astra Internasional, Tbk \\
\hline 2 & AUTO & Astra Otopart, Tbk \\
\hline 3 & BRAM & Indo Kortsa, Tbk \\
\hline 4 & GDYR & Goodyear Indonesia, Tbk \\
\hline 5 & GJTL & Gajah Tunggal, Tbk \\
\hline 6 & MASA & Multistrada Arah Sarana, Tbk \\
\hline 7 & IMAS & Indomobil Sukses Internasional, Tbk \\
\hline 8 & SMSM & Selamat Sempurna, Tbk \\
\hline \multicolumn{3}{|c|}{ Sumber:www.idx.co.id. }
\end{tabular}

\section{E. Variabel Penelitian}

1. Variabel X Menurut Sugiyono (2017:39), variabel bebas (independen variabel) merupakan variabel yang mempengaruhi atau yang menjadi sebab pembahasannya atau timbulnya variabel dependen. Variabel dalam penelitian ini adalah $\mathrm{X}=$ Net Pofit Margin. 


\section{Variabel $\mathrm{Y}$}

Menurut Sugiyono (2017:39), variabel terikat merupakan variabel yang dipengaruhi atau yang menjadi akibat, karena adanya variabel bebas. Variabel terikat dalam penelitian ini adalah $\mathrm{Y}=$ Return Saham.

\section{F. Sumber Data}

Penelitian ini menggunakan data sekunder, dengan bersumber dari data yang berasal dari data tahunan publikasi perusahaan yang diterbitkan oleh Bursa Efek Indonesia tahun 2015, 2016, 2017, dan 2018.

\section{G. Teknik Pengumpulan Data}

Teknik pengumpulan data yang dilakukan dalam penelitian ini adalah sumber data sekunder berupa dokumentasi dan studi pustaka atau literatur melalui buku teks, jurnal ilmiah, artikel, dan sumber tertulis lainnya yang berkaitan dengan informasi yang dibutuhkan sebagai sumber pengumpulan data, yaitu perusahaan pada sektor otomotif dan komponen yang terdaftar di Bursa Efek Indonesia pada periode 2015, 2016, 2017, dan 2018.

\section{H. Teknik Analisis Data}

1. Uji Normalitas

Menurut Priyatno (2018:33), normalitas data merupakan syarat pokok yang harus dipenuhi dalam analisis parametrik. Normalitas data merupakan hal yang penting karena dengan data yang terdistribusi normal, maka data tersebut dianggap dapat mewakili populasi.

Dalam penelitian ini uji normalitas data menggunakan uji skewness dan kurtosis. Pengambilan keputusan dalam uji skewness dan kurtosisadalah jika nilai rasio skewness dan kurtosis berada diantara -2 dan +2 , maka distribusi data adalah normal.

\section{Analisis Regresi Linier Sederhana}

Menurut Priyatno (2018:93) analisis regresi linier sederhana adalah analisis untuk mengetahui pengaruh atau hubungan secara linier antara net profit margin dengan return saham dan mempredeksi atau meramalkan nilai variabel dependen dengan menggunakan variabel independen.

a. Output Model Summary

Output ini menjelaskan tentang ringkasa model yang terdiri dari hasil nilai korelasi sederhana $(R)$, koefisien determinasi $(R)$ determinasi yang disesuaikan (Adjusted $R$ Square), dan ukuran kesalahan prediksi (Std Error if the estimate).

b. Output Coeffients

Menjelaskan tentang nilai koefisien, nilai t hitung, dan signifikansi.Persamaan regresi untuk regresi linier sederhana sebagai berikut: $Y=a+b X$

Keterangan :

$X$ : Variabel Independen, $a=$ konstanta, yaitu nilai $Y$ jika $X=0, b=$ koefisien regresi linear sederhana, yaitu nilai peningkatan atau penurunan variabel $Y$ tab didasarkan variabel $\mathrm{X}, \mathrm{Y}$ : nilai variabel dependen.

3. Analisis Korelasi Sederhana

Menurut Priyatno (2018:87) analisis korelasi sederhana digunakan untuk mengetahui hubungan antara dua variabel yang mempunyai distribusi dan data normal. Dalam perhitungan koelasi pearson akan di dapat koefisien korelasi yang 
menunjukan keeratan hubungan antara dua variabel tersebut. Nilai korelasi berkisar antar 0 sampai 1.

Tabel 2

Inteprestasi Koefisien

\begin{tabular}{|c|c|l|}
\hline No & Interval Koefisien & \multicolumn{1}{|c|}{ Tingkat Hubungan } \\
\hline 1 & $0,80-10,00$ & Sangat kuat \\
\hline 2 & $0,60-0,799$ & Kuat \\
\hline 3 & $0,40-0,599$ & Sedang \\
\hline 4 & $0,20-0,399$ & Rendah \\
\hline 5 & $0,00-0,199$ & Sangat rendah \\
\hline
\end{tabular}

Sumber:www.idx.co.id.

4. Uji Hipotesis ( Uji t)

Pengujian hipotesis digunakan untuk memperkuat hasil hitungan yaitu dengan menggunakan nilai t. Uji t dilakukan untuk mengetahui ada tidaknya pengaruh yang signifikan antara dua variabel. Menurut Priyatno (2018:58) uji t digunakan untuk mengetahi apakah variabel independen berpengaruh secara signifikan terhadap variabel dependen sigfnifikan artinya berarti atau pengaruh terjadi dapat berlaku untuk populasi.

Langkah-langkah uji t sebagai berikut:

a. Menentukan Hipotesis

$\mathrm{H}_{0}$ : Tidak ada pengaruh yang signifikan antara pengaruh Net Proft Margin terhadap Return Saham pada perusahaan sektor otomotif dan komponen yang terdaftar di BEl.

$\mathrm{H}_{\mathrm{a}}$ : Ada pengaruh signifikan antara Net Profit Margin terhadap Return Saham pada perusahaan sektor otomotif dan komponen yang terdaftar di BEl.

b. Ketika pengujian berdasarkan signifikan, yaitu: bila tingkat signifikan kurang dari 0,05 (sig < 0,05), maka $\mathrm{H}_{\mathrm{a}}$ diterima dan $\mathrm{H}_{\mathrm{o}}$ ditolak, terdapat pengaruh NPM terhadap Return Saham. Bila tingkat signifikan lebih dari 0,05 (sig > 0,05), maka $\mathrm{H}_{\mathrm{a}}$ ditolak dan $\mathrm{H}_{\mathrm{o}}$ diterima, tidak terdapat pengaruh NPM terhadap Return Saham.

\section{HASIL PENELITIAN DAN PEMBAHASAN}

1) Hasil Penelitian

a. Uji Normalitas

Menurut Priyatno (2018:73) uji normalitas merupakan analisis parametrik, seperti analisis Korelasi Pearson, Independen Samples T test, One Way ANOVA dan sebagainya, maka perlunya dilakukan uji normalitas data terlebih dahulu untuk mengetahui apakah berdistribusi normal atau tidak. Berikut ini yang dibahas uji normalitas menggunakan data dengan skewness dan kurtosis.

Tabel 3

Hasil Output Uji Normalitas

Descriptive Statistics

\begin{tabular}{|l|r|r|r|r|r|r|}
\hline & \multicolumn{1}{|c|}{$\mathrm{N}$} & \multicolumn{1}{c|}{ Mean } & \multicolumn{2}{|c|}{ Skewness } & \multicolumn{2}{|c|}{ Kurtosis } \\
\cline { 2 - 7 } & Statistic & Statistic & Statistic & Std. Error & Statistic & Std. Error \\
\hline In_x1 & 32 & 1,4884 &,- 945 &, 414 &, 861 &, 809 \\
In_y & 32 & 2,8274 & $-1,020$ &, 414 & 1,254 &, 809 \\
Valid (listwise) & 32 & & & & & \\
\hline
\end{tabular}

Sumber: Data sekunder diolah, 2019 
Berdasarkan hasil output uji normalitas di atas, maka dapat disimpulkan sebagai berikut:

1) Skewness, yaitu ukuran distribusi data untuk mengetahui apakah data distribusi dengan normal atau tidak, maka dihitung rasio skewness dengan perhitungan skewness adalah sebesar disimpulkan data skewness berdistribusi normal.

$-0,945 / 0,414=0,228$, hal ini dapat

2) Kurtosis, sama halnya dengan Skewness juga digunakan untuk mengukur distribusi data. Untuk mengetahui apakah data terdistribusi dengan normal atau tidak. Dihitung rasio kurtosis dengan perhitungan kurtosis/ standar error og kurtosis adalah sebesar 0,861/0,809=1,064 hal ini dapat disimpulkan data kurtosis berdistribusi Normal.

\section{b. Regresi Linier Sederhana}

Hasil untuk mengetahui apakah terdapat pengaruh Net Pofit Margin terhadap Return Saham, nilai taksiran koefisien regresi (a dan b) diperoleh dengan perhitungan pada tabel berikut ini:

Tabel 4

Coefficient

\begin{tabular}{|c|c|c|c|c|c|}
\hline \multirow[b]{2}{*}{ Model } & \multicolumn{2}{|c|}{$\begin{array}{l}\text { Unstandardized } \\
\text { Coefficients }\end{array}$} & $\begin{array}{l}\text { Standarddized } \\
\text { Coeffients }\end{array}$ & \multirow[b]{2}{*}{$\mathrm{t}$} & \multirow[b]{2}{*}{ Sig. } \\
\hline & $\mathrm{B}$ & Std. Error & Beta & & \\
\hline \multirow{2}{*}{$\begin{array}{ll}1 & \text { (Constant) } \\
& \ln \_x 1\end{array}$} & 3,388 & ,393 & \multirow[b]{2}{*}{,- 353} & 8,618 &, 000 \\
\hline &,- 377 &, 182 & & $-2,065$ &, 048 \\
\hline
\end{tabular}

Sumber: Data sekunder diolah, 2019

Berdasarkan output di atas diperoleh nilai a (konstanta) 3,388, nilai b -0,377. Sehingga diperoleh persamaan yaitu: $Y=3,388-0,377$.

Berdasarkan persamaan di atas dapat diinterprestasikan bahwa (konstanta) yaitu 3,388, artinya jika variabel independen nilainya adalah 0, maka Return Saham akan tetap sebesar 3,388. Sedangkan Net Profit Margin memiliki koefisien regresi mempunyai arah negatif yaitu $-0,377$, artinya setiap perubahan variabel NPM (X)sebesar 1\%, maka akan mengakibatkan perubahan Return Saham sebesar 0,377 .

Menurut Priyatno (2018:100), determinasi digunakan menunjukkan angka ini akan diubah persen, yang artinya persentase sumbangan pengaruh Net Profit Margin terhadap Return Saham. Apabila $\mathrm{R}^{2}$ sama dengan 0, maka variasi independen yang digunakan dalam model tidak menjelaskan $100 \%$ variasi variabel dependen. Adapun hasil pengolahan data sebagai berikut:

Tabel 5

Hasil Koefisien Determinasi

\begin{tabular}{|c|c|c|c|c|}
\hline Variabel & $\mathrm{R}$ & $\mathrm{R}$ Square & $\begin{array}{c}\text { Adjusted } \\
\mathrm{R} \text { Square }\end{array}$ & $\begin{array}{c}\text { Std. Error of the } \\
\text { Estimate }\end{array}$ \\
\hline 1 &,$- 353^{\mathrm{a}}$ &, 124 &, 095 & 1,60878 \\
\hline
\end{tabular}

$\mathrm{KD}=\mathrm{R}^{2} \times 100 \%$

$=0,124 \times 100 \%=12,4 \%$ 
Berdasarkan hasil di atas dijelaskan bahwa nilai koefisien determinasi $\left(R^{2}\right)$ sebesar $12,4 \%$ yang artinya menunjukan bahwa pengaruh variabel Net Profit Margin terhadap Return Saham sebesar 12,4\%. Sedangkan sisanya sebesar 87,6\% dipengaruhi oleh variabel lain, faktor-faktor lain yang tidak termasuk dalam penelitian ini.

\section{c. Analisis Korelasi Sederhana}

Menurut Priyatno (2018:87), analisis korelasi sederhana merupakan yang digunakan untuk mengetahui hubungan antara dua variabel, yaitu untuk mengetahui seberapa kuat hubungan apakah positif atau negatif, dan apakah hubungan signifikan atau tidak. Nilai koefisien korelasi berkisar antara 0 sampai 1 atau $p$ sampai -1. Apabila nilai makin mendekati 1 atau -1 , hubungan akan makin erat, sedangkan jika mendekati 0 , hubungan makin lemah.

Tabel 6

Correlations

\begin{tabular}{|ll|r|r|}
\hline & & \multicolumn{1}{|c|}{$\ln \_x 1$} & \multicolumn{1}{|c|}{$\ln \_y$} \\
\hline In_x1 & Pearson & 1 &,$- 353^{*}$ \\
& Correlation & &, 048 \\
& Sig. (2-tailed) & & 32 \\
& N & 32 & 1 \\
\hline In_y & Pearson &,$- 353^{*}$ & \\
& Correlation &, 048 & \\
& Sig. (2-tailed) & 32 & 32 \\
\hline
\end{tabular}

Sumber: Data sekunder diolah,2019

Berdasarkan hasil dari SPSS tersebut diketahui bahwa NPM diperoleh Pearson Correlation sebesar $-0,353$. Ini berarti terdapat hubungan yang signifikan secara negatif terhadap return saham yang berada pada tingkat sedang. signifikansi (sig 2tailed) sebesar 0,048 $<0,05$, maka $\mathrm{H}_{\mathrm{a}}$ diterima. $\mathrm{H}_{\mathrm{o}}$ ditolak. Jadi, dapat disimpulkan bahwa ada hubungan antara Net Profit Margin dengan Return Saham.

\section{d. Pengujian Hipotesis (Uji t)}

Menurut Priyatno (2018:104), Uji t ini untuk digunakan mengetahui apakah variabel independen (Net Profit Margin) berpengaruh secara sigifikan atau tidak terhadap variabel dependen (Return Saham). Hasil pengelohan data sebagai berikut:

Tabel 7

Hasil Uji T NPM Terhadap Return Saham

Coefficients

\begin{tabular}{|l|r|r|r|r|r|}
\hline \multirow{2}{*}{ Model } & \multicolumn{2}{|c|}{$\begin{array}{c}\text { Unstandardized } \\
\text { Coefficients }\end{array}$} & $\begin{array}{c}\text { Standarddized } \\
\text { Coeffients }\end{array}$ & \multirow{2}{*}{$\mathrm{t}$} & \multirow{2}{*}{ Sig. } \\
\cline { 2 - 3 } & $\mathrm{B}$ & \multicolumn{1}{c|}{ Std. Error } & Beta & & \\
\hline \multirow{2}{*}{$\begin{array}{l}\text { (Constant) } \\
\text { In_x1 }\end{array}$} & 3,388 &, 393 & & 8,618 &, 000 \\
\cline { 2 - 4 } &,- 377 &, 182 &,- 353 & $-2,065$ &, 048 \\
\hline
\end{tabular}

Sumber: Data sekunder diolah, 2019 
Berdasarkan hasil tabel di atas, maka menunjukkan bahwa nilai signifikan Net Profit Margin terhadap Return Saham adalah sebesar $0,048<0,05$ artinya $H_{\circ}$ ditolak, $\mathrm{H}_{\mathrm{a}}$ diterima, maka terdapat pengaruh signifikan antara Net Profit Margin terhadap Return Saham pada sektor otomotif dan komponen.

\section{2) Pembahasan}

Berdasarkan uji di atas dapat diinterprestasikan bahwa konstanta yaitu 3,388, artinya jika variabel independen nilainya adalah 0, maka Return Saham akan tetap sebesar 3,388. Sedangkan Net Profit Margin memiliki koefisien regresi mempunyai arah negatif yaitu $-0,377$, artinya setiap penurunan variabel NPM (X) sebesar $1 \%$, maka akan mengakibatkan perubahan Return Saham sebesar -0,377.

Hasil dari uji t, maka menunjukan bahwa nilai signifikan Net Profit Margin terhadap Return Saham adalah sebesar 0,048 $<0,05$ dengan demikian $\mathrm{H}_{\mathrm{o}}$ ditolak, $\mathrm{H}_{\mathrm{a}}$ diterima, maka dapat disimpulkan bahwa NPM berpengaruh positif signifikan terhadap return saham, dikarenakan adanya peningkatan pendapatan penjualan, maka bagi pihak perusahaan bahwa tinnginya pendapatan penjualan berpengaruh positif bagi perusahaan untuk menerapkan atau pengaruh return saham.

\section{J. KESIMPULAN DAN SARAN}

1) Kesimpulan berikut:

Berdasarkan hasil penelitian dan pembahasan didapatkan kesimpulan sebagai

a. Berdasarkan uji nilai koefisien korelasi sederhana diperoleh kesimpulan bahwa Net Profit Margin mempunyai hubungan yang signifikan terhadap Return Saham.

b. Net Profit Margin(NPM) berpengaruh positif dan signifikan terhadap Return Saham pada perusahaan sektor otomotif dan komponen yang terdaftar di Bursa Efek Indonesia tahun 2015-2017. Dengan demikian, nilai Net Profit Margin meningkat, maka baik bagi perusahaan untuk memberikan kostribusi kepada masyarakat dan penjualan.

c. Net Profit Margin secara parsial (bersama-sama) berpengaruh positif signifikan terhadap Return Saham. Dapat dilihat dari nilai koefisien determinasi $\left(\mathrm{R}^{2}\right)$ sebesar $12,4 \%$ nilai ini dapat didefinisikan bahwa 12,4\%. Sedangkan sisanya sebesar $87,6 \%$ dipengaruhi oleh variabel lain, faktor-faktor lain yang tidak termasuk dalam penelitian ini.

d. Sama seperti dengan uji yang lainnya di atas, maka uji t menunjukan bahwa nilai signifikan Net Profit Margin terhadap Return Saham adalah sebesar 0,048< 0,05 ini berarti $\mathrm{H}_{\mathrm{o}}$ ditolak, $\mathrm{H}_{\mathrm{a}}$ diterima, maka terdapat pengaruh signifikan antara Net Profit Margin terhadap Return Saham pada perusahaan sektor otomotif dan komponen Tbk.

\section{2) Saran}

Saran-saran yang dapat diajukan dalam penelitian ini adalah sebagai berikut:

a. Bagi investor atau calon investor yang akan menginvestasikan dananya agar dapat memperhatikan besaran pengaruh dari laba yang akan dicapai oleh suatu perusahaan terhadap Return Saham (deviden/capital gain) yang akan dibagi oleh perusahaan dalam suatu periode dimasa yang akan datang. Hal ini dapat dijadikan suatu prediksi untuk kelangsungan perusahaan.

b. Bagi perusahaan emiten agar lebih memperhatikan perbandingan antara tingkat Return Saham yang diberikan kepada investor dengan tingkat penanaman modal kembali (laba ditahan), karena hal ini menjadi salah satu 
faktor penting bagi para investor maupun calon investor untuk menanamkan modalnya atau dengan tingkat Return Saham yang akan dibagikan oleh perusahaan.

\section{DAFTAR PUSTAKA}

Diana, Shinta Rahma. 2018. Analisis Laporan Keuangan. Bogor: Penerbit In Media.

Fahmi, Irham. 2015. Pengantar Pasar Modal. Bandung: Alfabeta.

Hartono, Jogiyanto, 2015. Teori Portofolio dan Analisis Investasi. Edisi Kesepuluh. Yogyakarta:BPFE.

Jogiyanto, H.M. 2010. Teori Portofolio dan Analisis Investasi. Edisi Ketujuh. BPFE. Yogyakarta.

Kasmir. 2014. Analisis laporan Keuangan. Jakarta: Penerbit PT Rajagrafindo.

Priyatno, Duwi. 2018. SPSS Panduan Mudah oleh Data bagi Mahasiswa dan Umum. Yogyakarta: Percetakan CV Andi Offset.

Sugiyono. 2017. Statistika Untuk Penelitian. Bandung. Penerbit: ALFABETA.

Sunariyah. 2011. Pengantar Pengetahuan Pasar Modal. Edisi Keenam Yogyakarta:UPP STIM YKPN.

Widoatmodjo, Sawidji. 2015. Pengetahuan Pasar Modal untuk Konteks Indonesia. Yogyakarta: Gramedia.

www.idx.co.id 